\title{
MIR155 Gene
}

National Cancer Institute

\section{Source}

National Cancer Institute. MIR155 Gene. NCI Thesaurus. Code C81744.

This gene is involved in the regulation of gene expression and plays a potential tumor suppressor role in breast and pancreatic carcinomas, acute lymphoblastic leukemia and diffuse large B-cell lymphoma. 